Jurnal Interpretasi Hukum | ISSN: 2746-5047

Vol. 2, No. 3-Desember 2021, Hal. 479-483| Tersedia online di

https://www.ejournal.warmadewa.ac.id/index.php/juinhum

DOI: https://doi.org/10.22225/juinhum.2.3.4123.479-483

\title{
PELAKSANAAN TRADISI PERKAWINAN MERARIQ (BESEBO) SUKU SASAK DI LOMBOK TIMUR
}

\author{
Ratu Mutiah Ilmalia, I Nyoman Putu Budiartha, Diah Gayatri Sudibya \\ Fakultas Hukum, Universitas Warmadewa, Denpasar-Bali, Indonesia \\ ilmaliaratu@gmail.com, budiarthaputu59@gmail.com, diahgayatrisudibya@gmail.com
}

\begin{abstract}
Abstrak
Tradisi Perkawinan Merariq (Besebo) yakni tradisi perkawinan adat yang berada di Suku Sasak, dimulai dari peristiwa Memaling disebut juga mencuri atas dasar persetujuan perempuan yang haknya masih berada dalam kekuasaan orang tuanya, untuk membuktikan sebagai wujud sikap kesatria sekaligus bentuk keseriusan si lakilaki untuk menikahi si gadis. Setiap profesi Merariq memiliki nilai atau moral kehidupan yang bisa menjadikan sebuah pegangan hidup bagi masyarakat. Tujuan penelitian ini untuk mengungkap pelaksanaan perkawinan tradisi merariq (besebo) pada suku sasak di Lombok Timur serta penerapan tradisi perkawinan merariq (besebo) menurut Undang-undang No 1 Tahun 1974 dan Kompilasi Hukum Islam (KHI). Tipe penelitian yang digunakan yaitu penelitian hukum empiris dengan pendekatan pendekatan perundang-undangan dan pendekatan kasus. Teknik pengumpulan data dalam penelitian hukum normatif dilakukan dengan studi pustaka terhadap bahanbahan hukum. Sumber bahan hukum yang digunakan yaitu data primer dan sekunder. Adapun teknik analisis data dilakukan dengan deskriptif analitis. Hasil penelitian mengungkapkan bahwa didalam tradisi merariq di daerah Suku Sasak mempunyai gambaran tradisi perkawinan dengan berbagai macam ritual, dimana ritual adatnya mampu memberikan nilai sosial, dan pesan moral yang sangat melekat pada masyarakat Suku Sasak di Lombok Timur
\end{abstract}

Kata Kunci: Merariq (Besebo), Suku Sasak, Tradisi

\begin{abstract}
The Merariq (Besebo) Marriage Tradition is a traditional marriage tradition in the Sasak Tribe, starting from the Memaling incident, also called stealing on the basis of the consent of a woman whose rights are still in the power of her parents, to prove as a form of chivalry as well as a form of the man's seriousness to marry the girl. Every Merariq profession has values or morals of life that can become a guide for life for the community. The purposes of this study are to reveal the implementation of the merariq (besebo) marriage tradition in the Sa sak tribe in East Lombok and the application of the merariq (besebo) marriage tradition according to Law No. 1 of 1974 and the Compilation of Islamic Law (KHI). The type of research used is Empirical Law research with a statutory approach and case approach. Data collection techniques in normative legal research are carried out by literature studies on legal materials. Sources of legal materials used are primary and secondary data. The data analysis technique is done by analytical descriptive. The results of the study revealed that the merariq tradition in the Sasak Tribe area has a picture of the marriage tradition with various rituals, where the traditional rituals are able to provide social value, and a moral message that is very attached to the Sasak people in East Lombok.
\end{abstract}

Keywords: Merariq (Besebo), Sasak Tribe, Tradition

\section{PENDAHULUAN}

Di Dalam perikatan adat perkawinan diartikan sebagai suatu hubungan yang memiliki akibat hukum terhadap adat istiadat masyarakat yangbersangkutan dalam suatu daerah atau lingkungan adat. Akibat hukum tersebut ada semenjak sebelum terjadinya peristiwa adat yaitu perkawinan antara seorang wanita dan seorang laki-laki, yakni seperti contoh adanya hubungan pelamaran yang dilakukan mempelai laki-laki ke rumah mempelai wanita, dan hubungan orangtua keluarga dari calon mempelai laki-laki maupun perempuan. Setelah terjadinya perkawinan, adanya sebuah hak serta kewajiban orang tua (anggota keluarga atau kerabat), menurut hukum adat setempat hak dan kewajiban itu menyangkut pada saat dilaksanakannya prosesi adat tersebut, dan peranan lanjutan mereka saat membina serta memelihara kerukunan dan juga keutuhan dari kehidupan anak-anak yang dilahirkan dari pernikahan mereka yang terikat dalam janji suci perkawinan. 
Suku sasak terdapat di Lombok, Nusa Tenggara Barat dimana Bahasa yang digunakan masyarakatnya pun juga Bahasa sasak. 90\% dari orang-orang Sasak menganut agama Islam, namun didalam kepercayaannya menganut praktik yang sedikit beda dengan umat muslim yang lainnya, yakni disebut Watu Telu, namun hanya Sebagian kecil orang Sasak sekitar 1\% yang menganut praktek ibadah seperti itu. Dalam Suku Sasak ada sedikit masyarakatnya juga menganut kepercayaan praislam yang biasanya disebut dengan Sasak Boda. Di wilayah Lombok Timur, pada suku sasak, mempunyai sebuah tradisi yang dikenal adanya Kawin lari yang disebut dengan merariq.merariq adalah suatu budaya kawin lari dalam tradisi Sasak. Dalam pelaksanaannya terdapat empat prinsip, yaitu yang pertama adalah kebanggaan seorang perempuan, keberdayaan seorang lelaki dan tidak keberdayaan perempuan, adanya rasa kebersamaan, serta keuntungan ekonomi dari kedua belah pihak yang melakukan perkawinan. Terdapat arti terselip dari kata merariq yakni keberanian kedua belah pihak untuk saling bertanggung jawab, keteguhan dalam rangka mewujudkan suatu pernikahan dan penyelesaian perkara melalui jalan musyawarah. Awalnya, merariq hanya merupakan istilah untuk sebuah tindakan membawa lari seorang gadis dengan maksud untuk menikahinya. Akan tetapi, istilah merariq sekarang digunakan untuk menyebut seluruh rangkaian perkawinan adat Sasak (Kusumawardana, 2021).

Merariq dapat disebut dengan kawin lari dimana merupakan sebuah proses awal yang dilakukan oleh pasangan pemuda dan pemudi untuk melaksanakan pernikahan yang akan membawa mereka menuju kebahagiaan. Merariq merupakan suatu kata yang sering digunakan masyarakat Suku Sasak dalam melakukan pelarian atau Kawin lari, yang mempunyai arti tindakan awal yang dilakukan seorang laki-laki untuk mengambil seorang perempuan yang diinginkan dengan tujuan untuk dilarikan, dan akan di sembunyikan di rumah keluarga pihak ketiga dari si laki-laki, bertujuan untuk menjadikan perempuan tersebut menjadi istrinya (Fazalani, 2018). Diuraikan perkawinan merariq adalah calon mempelai saling mencintai sesuai dengan amanat dari UU no 1 Tahun 1974 tentang perkawinan, khususnya dalam Pasal 2 ayat (1). Merariq (Pernikahan) ini merupakan suatu proses yang di dalamnya terdapat implementasi tiga hukum (Pluralisme hukum) sekaligus yaitu hukum Teologi (syariat), Custom (budaya) dan State (Negara) (Lukman, 2014).

Penelitian terdahulu yang relevan dengan penelitian ini mengungkapkan bahwa sistem merariq mempunyai penyelesaian berupa pelaksanaan negosiasi antara perwakilan pihak calon mempelai lakilaki dengan keluarga calon mempelai perempuan yang diistilahkan dengan selabar untuk menyepakati pembayaran ajikrame dan pisuke guna menuju perdamaian para pihak (Haq, 2016). Selain itu merariq adalah ciri khas masyarakat Sasak yang dipertahankan keberadaannya selama merariq tersebut dijalankan sesuai dengan ketentuan adat yang berlaku (Anwar et al., 2019). Disisi lain, menurut Fitrianita et al, (2018) merarik seringkali meninggalkan kesan negatif sebab tidak jarang menimbulkan konflik antar keluarga. Namun hal ini tetap dipertahankan, sebab sudah menjadi tradisi dari suku sasak. Dari fenomena tersebut maka ingin dilakukan penelitian yang bertujuan untuk mengungkap pelaksanaan perkawinan tradisi merariq (besebo) pada suku sasak di Lombok Timur serta penerapan tradisi perkawinan merariq (besebo) menurut Undang-undang No 1 Tahun 1974 dan Kompilasi Hukum Islam (KHI).

\section{METODE PENELITIAN}

Tipe penelitian yang digunakan yaitu penelitian Hukum Empiris yaitu sebuah penelitian hukum yang fungsinya adalah yang bisa memandang bentukan hukum dan memiliki arti yang nyata dan meneliti cara bekerjanya produk hukum tersebut di ruang lingkup masyarakat. Penelitian ini juga meneliti perilaku hukum manusia dalam hubungan sosial kehidupan di lingkup masyarakat dan dinyatakan penelitian hukum ini diambil dari banyak fakta yang ada di dalam kehidupan sekelompok masyarakat. Jenis pendekatan yang digunakan oleh peneliti yakni pendekatan perundang-undangan, dan pendekatan kasus. Adapun teknik pengumpulan bahan hukum yang dipergunakan dalam penelitian ini adalah dengan mengkaji bahan hukum dari dokumen-dokumen hukum terikat (peraturan perundangundangan), dengan teknik mencatat. Sumber bahan hukum primer yang didapat dengan menganalisis peraturan perundang-undangan, risalah resmi, dan beberapa keputusan-keputusan yang menyangkut dengan judul tulisan ini. bahan hukum sekunder didapat dari menganalisis buku-buku, jurnal-jurnal dan hasil-hasil penelitian terdahulu yang memiliki keterkaitan dengan judul penelitian ini. Teknik analisis bahan hukum yang diaplikasikan untuk mengolah bahan hukum analisis data berupa deskriptif analitis. 


\section{HASIL DAN PEMBAHASAN}

\section{Pelaksanaan Perkawinan Tradisi Merariq (Besebo) pada Suku Sasak di Lombok Timur}

Tradisi merupakan suatu keseragaman benda atau material dan serta gagasan-gagasan dalam suatu kelompok masyarakat yang memang ada sejak zaman leluhur hingga sekarang ini serta juga tidak dapat dirusak melainkan selalu dijaga dan dibudayakan. Tradisi juga bisa dikatakan sebagai warisan masa lalu atau warisan yang benar. Kendati demikian, tradisi yang seringkali terjadi, atau rutin tidaklah dilakukan secara sengaja atau kebetulan saja (Sztompka, 2007).

Sebagai suatu sistem kebudayaan, tradisi tentunya selalu mengadakan berbagai macam model untuk menjadi acuan pergerakan yang memiliki sumber dari nilai-nilai dan gagasan utama atau Vital. Nilai-nilai dan gagasan utama dari tradisi mempunyai wujud sistem sosial, sistem ideologi masyarakat dan sistem teknologi. Sistem ideologis yakni etika atau norma yang memiliki fungsi terhadap landasan sistem sosial dan memiliki hubungan sosial di dalam kehidupan masyarakat.

Perkawinan adalah proses yang sudah lumrah di kehidupan masyarakat dan juga sudah melembaga, dimana seorang lelaki dan seorang wanita memiliki suatu ikatan cinta dan juga hubungan timbal balik atas dasar suka-sama suka yang adalah suatu dasar dari terbentuknya rumah tangga. Perkawinan antara lelaki dan perempuan akan menimbulkan suatu kewajiban dan juga hak baik diantara pasangan suami istri dan juga keturunan yang dilahirkan dari pernikahan keduanya (Artadi, 1987).

Perkawinan dalam ikatan adat adalah suatu proses yang memiliki akibat hukum diantara keduanya (laki-laki dan perempuan) terhadap hukum adat yang diberlakukan dalam kehidupan masyarakat yang bersangkutan tergantung dengan tempatnya. Perkawinan yang bersifat kekerabatan merupakan suatu perkawinan yang bertujuan untuk dapat meneruskan dan juga mempertahankan keturunan menurut garis kebapakan atau keibuan atau keibubapaan, hal ini juga dilakukan untuk kebahagiaan rumah tangga keluarga, untuk memperoleh nilai-nilai adat budaya dan kedamaian serta juga bisa mempertahankan warisan leluhur (Sulkhad, 2013).

Merariq tidalah memiliki arti yang sama seperti kawin lari pada umumnya, namun apabila diartikan dalam bahasa indonesia pandangan masyarakat yang paling mencolok atau mendekati artinya adalah kawin lari merariq yang ada dalam masyarakat suku sasak terkandung sebuah nilai luhur di dalam kehidupan masyarakat, merariq dilakukan sesuai dengan aturan dan adat masyarakat yang ada di daerah tersebut. nilai yang terdapat pada kehidupan yang terkandung dalam budaya merariq ini juga ditanamkan sebagai pendidikan yang ditanamkan untuk masyarakat dan akan diteruskan menjadi generasi kedepannya.

Tradisi merariq ini memiliki gambaran bagaimana terjadinya dalam suatu perkawinan mempunyai berbagai ritual adat yang memiliki pesan moral dan nilai sosial yang erat dan diyakini dalam masyarakat. Tradisi merariq juga mempunyai gambaran dimana suatu tradisi yang menjadi pegangan hidup dalam melaksanakan kehidupan. Merariq merupakan adat istiadat dalam suatu pernikahan antara seorang laki-laki dan seorang perempuan yang dimiliki oleh masyarakat suku sasak, merariq ini merupakan prosesi turun temurun yang sudah menjadi identitas suku sasak. Alasan yang melatarbelakangi seseorang dalam melakukan prosesi ini adalah :

1. Karena adanya paksaan dari pihak pengantin laki-laki.

2. Karena tidak adanya persetujuan dari orang tua kedua belah pihak baik laki-laki maupun perempuan.

3. Karena prosesi pernikahan merariq merupakan kebiasaan yang lalu menjadi suatu adat istiadat yang menjadi wajah dari masyarakat suku Sasak.

Fenomena dari budaya merariq pada kehidupan masyarakat Sasak yaitu tidak lain untuk suatu perwujudan dalam hal kearifan lokal, dimana didalamnya juga ada keyakinan masyarakat untuk menunjukan suatu keberanian seorang laki-laki untuk calon istri yang akan di pinangnya.perkawinan merariq ini dilakukan hampir seluruh masyarakat adat dilatarbelakangi oleh pelestarian kearifan lokal kebudayaan. Alasan lain yakni karena tidak memiliki persetujuan dari orang tua mereka masingmasing mengenai hubungan yang dijalaninya dan akhirnya memilih cara merariq sebagai jalan keluar untuk hubungan tersebut.

Dampak yang disebabkan dari prosesi adat merariq yakni banyaknya perempuan suku Sasak yang menikah muda (pernikahan dini), apabila dipandang dari segi kesehatan, usia pernikahan dini yang sering terjadi pada perempuan khususnya dalam suku Sasak, memiliki banyak masalah yang 
muncul, hal ini dapat disebabkan oleh fisik maupun mental yang tidak siap untuk kehidupan berumah tangga. Ketidaksiapan fisik ini tentunya akan menimbulkan kesehatan perempuan akan terganggu, dan Rahim belum siap untuk berproduksi atau membuahi, dan juga akan terjadi konflik yang tidak diinginkan karena dimana pada usia muda cepat terjadi perubahan emosional terjadi.

\section{Penerapan Tradisi Perkawinan Merariq (Besebo) Menurut Undang-undang No. 1 Tahun 1974 dan Kompilasi Hukum Islam (KHI)}

Kompilasi Hukum Islam (KHI) merupakan istilah untuk menunjukkan suatu kaidah-kaidah atau norma hukum dalam islam yang sumbernya dari keempat mazhab fikih. Seluruh pendapat para ulama yang bersangkutan dengan ilmu fikih akan disatukan dalam bentuk sebuah buku yang disusun dengan bahasa perundang-undangan (Red \& Rizqa, 2020). Di Dalam KHI tidak ada perbedaan diantara hal yang disebut rukun dan/atau syarat sah nya perkawinan menurut Islam. Keduanya merupakan satu kesatuan yang tidak bisa untuk dipisahkan. Rukun Perkawinan ini diatur dalam Pasal 14 Kompilasi Hukum Islam (KHI), dimana untuk melaksanakan perkawinan harus ada nya :

1. Calon Istri (seorang wanita) dan juga calon suami (seorang laki- laki)

2. Wali nikah dari pihak wanita

3. Adanya 2 orang saksi nikah

4. Adanya ijab dan Kabul yang dilakukan oleh penghulu yang sah

Selain hal tersebut perkawinan juga memiliki tujuan untuk menyatukan kedua keluarga/kerabat baik dari pihak laki maupun perempuan. Oleh karena itu perkawinan bukanlah hanya mengenai urusan pribadi dua orang yang menikah saja, melainkan menjadi urusan kedua keluarga/kerabat pihak laki-laki maupun perempuan, bahkan menjadi urusan masyarakat adat sekitar. Masyarakat Sasak yang Sebagian besar penduduknya menganut agama Islam ini memandang proses perkawinan perintah agama, dalam rasya syukur kehadirat allah swt, dikarenakan suku sasak bermayoritas muslim, maka perkawinan harus segera dilakukan, karena itu adalah sunnah yang memiliki dampak kebaikan.

Perkawinan dapat dikatakan, jika dilakukan menurut hukum masing- masing agama dan kepercayaan, sesuai dengan ketentuan Pasal 2 ayat (1) Undang-undang Nomor 1 Tahun 1974 tentang perkawinan. Agar terjamin ketertiban perkawinan bagi masyarakat Islam setiap perkawinan harus dicatat dalam lembaran negara melalui buku nikah. Pencatatan perkawinan tersebut dilakukan oleh Pegawai Pencatat Nikah (KUA) sebagaimana yang diatur dalam Undang-undang Nomor 22 Tahun 1946 jo Undang-undang Nomor 32 Tahun 1954. Dalam melaksanakan suatu perkawinan diatur pada Undang-undang Nomor 1 Tahun 1974 tentang Perkawinan, Peraturan Pemerintah nomor 9 tahun 1975 tentang pelaksanaan Undang-Undang Nomor 1 tahun 1974 tentang perkawinan, kemudian Kompilasi Hukum Islam (KHI) yang disebarluaskan melalui Instruksi Presiden Nomor 1 tahun 1991. Dalam UU tersebutlah, perkawinan memiliki konsep sebagai hubungan lahir batin antara seorang laki- laki dan seorang perempuan. Tujuannya untuk membentuk sebuah keluarga kecil yang kekal dan bahagia berdasarkan Ketuhanan Yang Maha Esa. Dalam hal ini mencerminkan suatu harapan dari pembentuk undang-undang, suatu keluarga yang dibentuk atas perkawinan yang sah dan memiliki ketahanan konflik dan dapat berkontribusi positif kepada masyarakat dan masyarakat luas (Nuruddin \& Sukardja, 2004).

Dalam pelaksanaan adat perkawinan merariq Suku Sasak di Lombok Timur disebutkan, bahwa dalam Undang-undang No 1 Tahun 1974 hanya mengatur tentang perkawinan secara umum saja, termasuk didalamnya adalah tentang sahnya perkawinan. Tetapi dalam perkawinan merariq adalah kawin lari yang masih diakui dalam masyarakat adat di Lombok Timur, dan ada pengaturannya dalam peraturan yaitu Rat Sasak dalam Pasal 1 ayat (18), (19), (20), (21), (22), (23), dan (25). Setelah proses yang dijalani sudah sesuai dengan apa yang tertuang dalam Rat Sasak, maka akan dilaksanakan upacara Ijab Kabul yang sesuai dengan keyakinan Masyarakat Muslim dan sudah bisa dinyatakan sah perkawinan tersebut menurut ketentuan Undang-Undang No 1 Tahun 1974 yang termuat dalam Pasal 2 ayat (1).

\section{SIMPULAN DAN SARAN}

\section{Simpulan}

Pelaksanaan tradisi perkawinan Merariq (Besebo) pada masyarakat Suku Sasak di Lombok Timur merupakan langkah awal seorang pria untuk mendapatkan seorang wanita yang dia cintai dengan 
cara melarikan/mencuri si wanita dan disembunyikan di pihak ketiga atau rumah keluarga dari pihak laki-laki. Tindakan dalam lari bersama antara laki-laki dan perempuan ini dilakukan karena ada kemauan dan kesepakatan bersama antara mereka berdua, alasan mereka melakukan kawin lari karena atas dasar mereka saling mencintai. Merariq adalah bukti bahwa seorang laki-laki memiliki keberanian seorang perempuan yang ingin dijadikan isterinya, dan dalam sebuah tradisi merariq ini resiko seorang laki-laki harus berani bertanggung jawab atas apa yang dia lakukan. Adapun penerapan tradisi perkawinan merariq (Besebo) menurut Undang- Undang No 1 tahun 1974 dan Kompilasi Hukum Islam sudah memenuhi syarat dan ketentuan yang berlaku dalam syariat islam adalah sah baik secara hukum positif maupun hukum islam, dikarenakan perkawinan merariq proses adat-istiadatnya saja yang berbeda sedangkan yang lain sama mengikuti ketentuan Undang- Undang No 1 Tahun 1974, perkawinan menurut hukum islam yakni memilki keturunan dalam ikatan perkawinan, menjadikan rumah tangga yang bahagia dan kekal, tujuan perkawinan agar mendapat ridha dari yang maha kuasa dan mempunyai keturunan, agar terhindar dari maksiat dan zina. Di suatu perkawinan yang dilakukan diluar pencatatan nikah dan tidak mempunyai kekuatan hukum, bisa mengajukan itsbat nikahnya ke pengadilan agama.

\section{Saran}

Masyarakat sasak seharusnya tidak menyalahgunakan adat merariq sebagai suatu alat yang tidak dibenarkan atas dasar kepentingan sepihak. Kontrol dari pihak masyarakat suku Sasak sangat diperlukan untuk menghindari terjadinya kesalahan norma dalam penerapan adat istiadat perkawinan merariq ini. Maka diperlukan peranan pemerintah dan suku adat untuk memperhatikan angka dari usia pernikahan dini yang disebabkan oleh proses perkawinan adat merariq, yang tentunya melibatkan lintas sektor pemerintahan terkait, seperti halnya tenaga kesehatan, tokoh Masyarakat yang dekat dengan sekitarnya, dan pemangku adat yang ada di wilayah setempat. Jika sudah terjadi prosesi merariq dan usia mempelai wanita masih dibawah umur, maka perlu dilakukan pencegahan kehamilan sampai usia perempuan matang dan rahimnya benar-benar siap untuk dibuahi. Hal ini juga diterapkan untuk menghindari ledakan jumlah masyarakat adat yang menikah usia dini khususnya pada perempuan.

\section{DAFTAR PUSTAKA}

Anwar, S., Hasan, N., \& Kurniawati, D. A. (2019). Praktek Budaya Merariq dalam Perspektif Hukum Islam (Studi Kasus Desa Tibu Sisok Kecamatan Janapria Kabupaten Lombok Tengah). Hikmatina, 1(2), 157-163.

Artadi, I. K. (1987). Hukum Adat Bali dengan Aneka Masalahnya dilengkapi Yurisprudensi. Setia Lawan, Denpasar.

Fazalani, R. (2018). Tradisi Bau Nyale Terhadap Nilai Multikultural pada Suku Sasak. Jurnal Pendidikan Bahasa Dan Sastra Indonesia, 3(2), 162-171.

Fitrianita, T., Kholifah, S., \& Adawiyah, R. (2018). Perempuan Nyurlembang dalam Tradisi Merarik. SIMULACRA, 1(2), 123-140.

Haq, H. S. (2016). Perkawinan Adat Merariq dan Tradisi Selabar di Masyarakat Suku Sasak. Jurnal Perspektif, 21(3), 157-167.

Kusumawardana, M. A. (2021). Keharmonisan dalam Tradisi Perkawinan Merariq di Lombok Sebagai Bentuk Pengalaman Al-Qur'an. Jurnal Studi Ilmu-Ilmu Al-Qur'an Dan Hadis, 22(1), 118.

Lukman, W. (2014). Eksistensi Perkawinan Masyarakat Suku Sasak Lombok (Merariq) dalam Muara Pluralisme Hukum. Jurnal IUS, 2(6), 427-444.

Nuruddin, A., \& Sukardja, A. (2004). Hukum Perdata Islam Indonesia; Studi Kritis Perke mbangan Hukum Islam dari Fikih, UU No 1/1974, sampai KHI. Kencana, Jakarta.

Red, A. Y., \& Rizqa, H. (2020). Sejarah Kompilasi Hukum Islam di Indonesia. Republika.co.id.

Sulkhad, K. (2013). Merariq Pada Masyarakat Sasak Sejarah, Proses Pandangan Islam. Penerbit Ombak, Yogyakarta.

Sztompka, P. (2007). Perubahan Sosial. Prenada Media Group, Jakarta. 